Creative Commons User License: CC BY-NC-ND

Abstracted by: EBSCOhost, Electronic Journals Service (EJS),

Google Scholar, Journal Seek, Scientific Commons,

Food and Agricultural Organization (FAO), CABI and Scopus
Journal of Agricultural Extension

Vol. 24 (1) January, 2020

ISSN(e): 24086851; ISSN(Print); 1119944X

http://journal.aesonnigeria.org

http://www.ajol.info/index.php/jae

Email: editorinchief@aesonnigeria.org

\title{
Use of Media Marketing Tools among Cassava Growers in Oyo State
}

https://dx.doi.org/10.4314/jae.v24i1.15

\author{
Adelakun, Olubunmi Jokotola \\ Institute of Agricultural Research and Training, Moor Plantation, Ibadan, Nigeria \\ olubunmiadelakun@gmail.com; +2348061613227
}

\section{Thomas, KehindeAdesina}

Department of Agricultural Extension and Rural Development, University of Ibadan, Ibadan, Nigeria

kehindeadesina@yahoo.com; +2348055951145

\section{Lawal, BosedeOlukemi}

Institute of Agricultural Research and Training, Moor Plantation, Ibadan, Nigeria

bosedelawal@gmail.com; +2348162005868

\section{Abstract}

The study investigated the level of use of Media Marketing Tools (MMTs) among cassava growers in Oyo State. Interview schedule was used to collect data from a sample size of 192 respondents across the senatorial districts of the state. Data was analysed using descriptive and inferential statistics. Results revealed that respondents' years of farming experience, marketing experience and annual income were $16 \pm 11.2$ years, $12.5 \pm 10.7$ years, and N625, 833.3 $416,367.2$, respectively. Despite wider spread and use of media marketing tools for agricultural products and services globally, use of MMTs was low in the study area. Unstable power supply $(x=2.0,0.00)$, high cost of devices for accessing media marketing tools $(x=1.98,0.10)$ and lack of technical know-how $\bar{x}=1.97,0.14)$ were identified as constraints to the use of the tools. Significant relationship existed between awareness ( $r=-0.57$, $p=0.00)$ and the use of media marketing tools, while knowledge ( $r=0.355$, $p=0.067)$ did not have significant association with the use of the tools. Hence, there is need for intensified awareness and training of cassava growers by all extension stakeholders on the use of MMTs for improved productivity.

Keywords: Cassava growers, marketing tools, cassava marketing

\section{Introduction}

Cassava is a cash crop across the globe, which has the highest production from Nigeria, (Ani, Agbugba, and Baiyegunhi, 2013). However, it generates low economic benefits to small and medium scale growers due to numerous marketing problems. Some of the marketing problems include lack of adequate or faulty marketing systems and strategies, instability in cassava production and price (Oni, 2016). Furthermore, Asogwa and Okwoche, (2012) identified poor market outlet, exploitative nature of middlemen who seem to be more actively involved in marketing and sales of the produce are other marketing challenges encountered by the 
Creative Commons User License: CC BY-NC-ND

Abstracted by: EBSCOhost, Electronic Journals Service (EJS), Google Scholar, Journal Seek, Scientific Commons,

Food and Agricultural Organization (FAO), CABI and Scopus
Journal of Agricultural Extension

Vol. 24 (1) January, 2020

ISSN(e): 24086851; ISSN(Print); 1119944X

http://journal.aesonnigeria.org

http://www.ajol.info/index.php/jae

Email: editorinchief@aesonnigeria.org

cassava growers. In addition, Bukar, Mohammed, Wakawa, Shettima and Muhammad, (2015) opined poor market information system as another marketing problem. Also, poor roads, underutilization of research findings emanating from research institutes and universities by farmers, lack of required modern marketing skills and lack of wider awareness about media marketing tools constitute marketing problems (Olaniyi, Adetumbi, and Adereti, 2013).

In other to proffer solutions to marketing problems, various concerned stakeholders developed myriad of technologies to tackle the problems. One of the strategies developed for solving the problems is the use of media marketing tools. Media marketing tools are product development, promotional strategies and action that a company or farmer can use to develop and promote its produce, products or services. They are also channels, applications, networks, innovations, and platforms developed for marketing produce (Madhu and Deepak, 2018; Anzaku and Salau, 2017). Examples of agricultural media marketing tools are market research surveys, television commercials, print advertisements, word-of-mouth (WOM), radio jingles, news releases, promotional items, road shows, agricultural exhibitions, customer loyalty programme, news media, pop-up adverts, search engine optimisation, mobile marketing and all digital media applications (Weir, 2019).

The advent of media marketing tools (MMTs) has revolutionized the way people advertise and market their produce worldwide. In a growing number of developed and developing countries, MMTs are being used to drive, increase, and market cassava produce effectively, often with positive dramatic results (Ariyo, 2013). Media marketing tools are useful in this highly dynamic, competitive, fast-paced, high technological advanced, and global marketplace generation. Part of the goals of agricultural media marketing tools for agricultural produce is to showcase products and services that customers/potential customers will buy through different platforms, help farmers in increasing produce/farm exposure, broaden customer reach, analyse customer needs, satisfy them and reap benefits. According to Adeniyi (2014), the use of media marketing tools helps in processing marketing information related to agricultural product and promotion. MMTs give an endless opportunities and ways to share content and attract new customers (Baltes, 2016). According to Kolawole, Lasisi, and Adeleke, (2017), the improvement in the use of MMTs for agricultural business has made farmers to adopt different media marketing tools available to them. This implies that agricultural environment and marketing strategies have gone through big changes due to media marketing tools.

Meanwhile despite the far-reaching influence and importance of MMTs, the use of the tools among famers has not been researched on extensively. In order to fill this gap, it is therefore imperative to assess the use of media marketing tools among cassava farmers in Oyo State which will invariably increase farmers' sales, improve their productivity and also country's development. Specifically, the study was designed to:

i. $\quad$ ascertain the respondents' knowledge on the use of MMTs;

ii. assess the type of MMTs used by the respondents; and 
Creative Commons User License: CC BY-NC-ND

Abstracted by: EBSCOhost, Electronic Journals Service (EJS), Google Scholar, Journal Seek, Scientific Commons,

Food and Agricultural Organization (FAO), CABI and Scopus
Journal of Agricultural Extension

Vol. 24 (1) January, 2020

ISSN(e): 24086851; ISSN(Print); 1119944X

http://journal.aesonnigeria.org

http://www.ajol.info/index.php/jae

Email: editorinchief@aesonnigeria.org

iii. identify constraints to the use of MMTs by the respondents.

\section{Hypotheses of the study}

Ho1: There is no significant relationship between enterprise characteristics and the use of MMTs among the cassava growers in the study area.

Ho2: There is no significant relationship between awareness and the use of MMTs among the cassava growers in the study area.

\section{Methodology}

This study was carried out in Oyo State, Nigeria. It is located in South-Western part, lies within latitude $8.41^{\circ} \mathrm{N}$ and longitude $3.42^{\circ} \mathrm{E}$, and has an estimated area of $27,249 \mathrm{~km}^{2}$. It is bounded in the South by Ogun State, in the North by Kwara State, west partly bounded by Ogun State and partly by Republic of Benin, East bounded by Osun State (Oyo State Diary, 2010). The ecological zone of this area ranges from rain forest and mangrove forest. The rainfall ranges from 2500 to $3000 \mathrm{~mm}$ per annum, which is distributed over April to October with a spell of dry period between November and March. Agricultural sector forms the base of the overall development thrusts of the area, with farming as the main occupation of the people. Crops usually grown include cassava, maize, yam, cocoyam, melon, cowpea, cashew and vegetables under mixed cropping practices. It consists of thirty-three local government areas, (LGAs) with three senatorial district and four zonal agricultural development programmes (ADPs) located at Saki, Ogbomosho, Oyo and lbadan/lbarapa.

he study population covers all registered cassava growers in Oyo State. Multi-stage sampling procedure was adopted to select respondents for the study. The first stage involved a purposive selection of all the senatorial districts in the state (Oyo Central, Oyo North and Oyo South), this is because Oyo is the state with highest cassava growers in South West Nigeria (FMARD, 2017), also to allow the research work to cover all the senatorial districts in the State. Stage two involved the purposive selection of one local government area from each of the three senatorial districts, based on the fact that, they are the local government areas with the highest population of cassava growers (FMARD, 2017). At the last stage, proportionate sampling technique was used to select $10 \%$ of the growers in the selected local governments from each of the senatorial districts, thus, 192 respondents were selected for this study. Data were collected with the use of structured interview schedule and key informants interview on respondents' enterprise characteristics and other variables specified in the objectives of this study. 
Creative Commons User License: CC BY-NC-ND

Abstracted by: EBSCOhost, Electronic Journals Service (EJS),

Google Scholar, Journal Seek, Scientific Commons,

Food and Agricultural Organization (FAO), CABI and Scopus
Journal of Agricultural Extension

Vol. 24 (1) January, 2020

ISSN(e): 24086851; ISSN(Print); 1119944X

http://journal.aesonnigeria.org

http://www.ajol.info/index.php/jae

Email: editorinchief@aesonnigeria.org

Table 1: Sampling frame and sample size

\begin{tabular}{llccc}
\hline $\begin{array}{l}\text { Senatorial } \\
\text { districts }\end{array}$ & $\begin{array}{l}\text { Selected } \\
\text { government areas }\end{array}$ & $\begin{array}{l}\text { local } \\
\text { registered } \\
\text { growers }\end{array}$ & $\begin{array}{c}\text { of } \\
\text { Cassava }\end{array}$ & $\begin{array}{l}\mathbf{1 0 \%} \text { of } \\
\text { selected } \\
\text { registered } \\
\text { Cassava growers }\end{array}$ \\
\hline Oyo Central & Atiba & 579 & 58 \\
Oyo North & Ogbomosho North & 602 & 60 \\
Oyo South & Ibarapa East & 739 & 74 \\
Total & & $\mathbf{1 9 2 0}$ & $\mathbf{1 9 2}$ \\
\hline
\end{tabular}

Source: Federal Ministry of Agriculture and Rural Development (FMARD), 2017

Respondents' awareness about the use of MMTs was measured by asking them to indicate from the stated options the media marketing tools they were aware of. 'Yes' responses were awarded score of 1 and 'no' were scored 0 . A total score for the awareness was computed, above and below mean criterion was used to categorise the scores into high and low.

Knowledge on the use of MMTs was ascertained by providing respondents with a list of 14 knowledge questions cutting across purpose, operationalisation, hazard and economic importance of using the tools. Respondents were asked to provide correct answers to the questions and correct option was scored 1, while wrong option was scored 0 . The correct responses from the respondents were summed and a mean knowledge score was generated, which was used as a bench mark to categorise them into high and low.

The 'use of MMTs' was measured by providing the respondents with a total number of 23 types of media marketing tools used to elicit marketing cassava produce/products. They were asked to state the type(s) being used and frequency of use from the options of: daily, monthly, quarterly, biannually and yearly, which was 6 , $5,4,3,2,1$, and 0 , respectively. An index was generated by adding all the responses and the mean score was computed which was used to as the benchmark to categorise respondents into having high and low use of media marketing tools. Data were analysed using descriptive and inferential statistics.

\section{Results and Discussion}

\section{Awareness of Media Marketing Tools}

Data in Table 2 reveal that all $(100 \%$, ) the cassava were aware of each of the following: newspaper adverts, banners, television adverts, radio adverts, words-ofmouth and signboards, respectively as tools for marketing their produce, while $99.5 \%$ were also aware of the use of posters for marketing. This corroborates the findings of Olaniyi et al (2013), which most cassava farmers in south west were aware of MMTs based on their availability. Results also show that, most $(77.6 \%)$ of the respondents had high level of awareness on use of media marketing tools for 
Creative Commons User License: CC BY-NC-ND

Abstracted by: EBSCOhost, Electronic Journals Service (EJS), Google Scholar, Journal Seek, Scientific Commons,

Food and Agricultural Organization (FAO), CABI and Scopus
Journal of Agricultural Extension

Vol. 24 (1) January, 2020

ISSN(e): 24086851; ISSN(Print); 1119944X

http://journal.aesonnigeria.org

http://www.ajol.info/index.php/jae

Email: editorinchief@aesonnigeria.org

cassava marketing, while (22.4\%) had low awareness on the use of the tools, with mean of $24.57 \pm 3.11$. This supports the finding of Fawole and Olajide (2012) that cassava farmers had high awareness about the MMTs for marketing.

Table 2: Awareness of media marketing tools

\begin{tabular}{ll}
\hline Media marketing tools & Aware(\%) \\
\hline Newspaper (Advertisement) & $100(192)$ \\
Business cards & $97.9(188)$ \\
Posters & $99.5(191)$ \\
Flyers & $93.2(179)$ \\
Banners & $100(192)$ \\
Stickers & $94.3(181)$ \\
Television (Advertisement) & $100(192)$ \\
Cinema & $85.4(164)$ \\
Radio & $100(192)$ \\
Words-of-Mouth & $100(192)$ \\
Trade fairs & $96.4(185)$ \\
Road shows & $0(0)$ \\
Promotional gift items & $93.2(179)$ \\
Signboards & $100(192)$ \\
Billboard (non-electronic) & $92.2(177)$ \\
Facebook & $92.2(177)$ \\
Twitter & $18.2(35)$ \\
Instagram & $2.6(5)$ \\
Whatspp & $65.1(125)$ \\
E-mail & $34.9(67)$ \\
SMS & $91.1(175)$ \\
Billboards (electronic) & $92.2(177)$ \\
Awareness & \\
Low $\leq 24.57$ & 22.4 \\
High>24.57 & 77.6
\end{tabular}

*Multiple responses. Source: Field survey, 2018

\section{knowledge of Use of Media Marketing Tools}

Results in Table 3 reveal that, more than half $(59.9 \%)$ of the respondents had low knowledge of media marketing tools for cassava marketing, while $(40.1 \%)$ had high knowledge on the use of media marketing tools with mean of 11.05 . This implies that low knowledge of the use of the tools was probably as a result of respondents' low disposition to the use of the tools in the study area. This supports the findings of Ajayi, Alabi and Okanlawon, (2018) which posited that farmers' knowledge on the use MMTs is low due to their perception and lack of technical know-how of the tools.

Table 3: Knowledge of respondents of media marketing tools

\begin{tabular}{llc}
\hline Variable & Percentage (\%) & Mean \pm SD \\
\hline Knowledge & & \\
Low $\leq 11.05$ & 59.9 & $11.05 \pm 1.57$ \\
High $>11.05$ & 40.1 & \\
\hline Source: Fin & &
\end{tabular}

Source: Field survey, 2018 
Creative Commons User License: CC BY-NC-ND

Abstracted by: EBSCOhost, Electronic Journals Service (EJS),

Google Scholar, Journal Seek, Scientific Commons,

Food and Agricultural Organization (FAO), CABI and Scopus
Journal of Agricultural Extension

Vol. 24 (1) January, 2020

ISSN(e): 24086851; ISSN(Print); 1119944X

http://journal.aesonnigeria.org

http://www.ajol.info/index.php/jae

Email: editorinchief@aesonnigeria.org

\section{Respondents Use of Media Marketing Tools}

Data in Table 4 show that five out of the twenty-three MMTs were being used by the respondents in the study area. Words-of-mouth, WhatsApp and Facebook were ranked $1^{\text {st }}, 2^{\text {nd }}$ and $3^{\text {rd }}$, respectively. The Table also reveals that majority $(80.2 \%)$ of the respondents had low use of the tools, which is a reflection of negative effects marketing strategies and consequently low sales of their produce. This supports the findings of Tiamiyu, Bankole, and Agbonlahor, (2012) that non-adoption and non-use of new technology bring about decrease in income and growth of a nation.

Table 4: Use of media marketing tools

\begin{tabular}{llll}
\hline Media Marketing Tools & Mean & S.D & $\%$ \\
\hline Words-of-Mouth & 4.00 & 0.00 & \\
WhatsApp & 2.22 & 0.65 & \\
Facebook & 0.69 & 1.51 & \\
Radio & 0.69 & 1.51 & \\
Instagram & 0.57 & 0.36 & \\
Use categorised $(7.65 \pm 3.26)$ & & & \\
Low & $\leq 7.65$ & & 80.2 \\
High & $>7.65$ & & 19.8 \\
\hline
\end{tabular}

Minimum score $=4.0$, maximum $=15.0$ and mean $=7.65$

Source: Field survey, 2018

\section{Constraints to Use of Media Marketing Tools}

Table 5 shows unstable power supply $(\bar{x}=2.0)$, high cost of devices for accessing media marketing tools $(\bar{x}=1.98)$ and network failure $(\bar{x}=1.97)$ as constraints associated with the use of the tools. This implies that, respondents were faced with numerous barriers, thereby limiting their extensive use of media marketing tools for marketing their produce/products. This supports the findings of Otitoju, Nweze, and Ezechie, (2014) that high cost of devices for accessing MMTs and lack of technical know-how are constraints to the use of the tools by farmers. Similarly, the review by Okeke, Nwalieji and Uzuegbunam (2015) revealed that insufficient knowledge of media marketing tools (MMTs) affects use of MMTs among farmers.

Table 5: Constraints to use of media marketing tools

\begin{tabular}{lll}
\hline Statements & mean & SD \\
\hline Unstable power supply & 2.00 & 0.00 \\
High cost of the devices for accessing MMTs & 1.98 & 0.10 \\
Network failure & 1.97 & 0.14 \\
Lack of technical know how & 1.65 & 0.47 \\
High cost of operating MMTs & 1.62 & 0.48 \\
Inadequate market information & 0.42 & 0.49 \\
Hazard through radioactive emission of the devices & 0.00 & 0.00 \\
\hline
\end{tabular}


Creative Commons User License: CC BY-NC-ND

Abstracted by: EBSCOhost, Electronic Journals Service (EJS),

Google Scholar, Journal Seek, Scientific Commons,

Food and Agricultural Organization (FAO), CABI and Scopus
Journal of Agricultural Extension

Vol. 24 (1) January, 2020

ISSN(e): 24086851; ISSN(Print); 1119944X

http://journal.aesonnigeria.org

http://www.ajol.info/index.php/jae

Email: editorinchief@aesonnigeria.org

Source: Field survey, 2018

Relationship between Enterprise Characteristics, Awareness, Knowledge and Use of media marketing tools

Results in Table 6 show that income $(r=0.222, p \leq 0.05)$ and marketing experience $(r=0.146, p \leq 0.05)$ had significant relationship with the use of MMT, while farming experience $(r=0.016, p \geq 0.05)$, and knowledge $(r=0.355, p \geq 0.05)$ were not significant. These show that income and marketing have influence on the adoption and use of tools for marketing. Increase in marketing experience exposes farmers to the necessity of using the tools and the higher the income the more the financial ability to make of MMTs. This avouch the findings of Lokeswari (2016) which posited it that more income motivates farmers to procure, access and possibly make use of the tools, hence the constraints associated with the use of MMTs. The table also reveals a significant relationship between awareness and the use of media marketing tools $(r=-0.572)$. The inverse relationship indicates that the higher awareness, the lower the use of the tools and that the lower the awareness, the higher the use of the tools, this is an indication that for the usage of MMTs to be high, the increased prominence of the awareness does not count. The corroborates the findings of Vassalos and Lim (2016) who posited that despite the awareness of the tools for marketing farmers are still not willing to make use of them, due to the constraints associated with the use of the tools.

Table 6: Correlation of enterprise characteristics, awareness, knowledge and use of media marketing tools

\begin{tabular}{ll}
\hline Variable & r-value \\
\hline Income & $0.222^{\star}$ \\
Farming experience & 0.016 \\
Marketing experience & $0.146^{\star}$ \\
Awareness on the use of MMTs & $-0.572^{\star}$ \\
Knowledge on the use of MMTs & 0.355 \\
\hline
\end{tabular}

${ }^{*} \mathrm{P} \leq 0.05$. Source: Field survey, 2018

\section{Conclusion and Recommendations}

There was low use of media marketing tools. Constraints to the use of the tools include unstable power supply, high cost of devices for accessing the tools, network failure, and lack of technical know-how. There is need for all concerned stakeholders (government, non-governmental organisations, research institutes, Universities, ministries of agriculture, agricultural development agencies and media houses) to improve their extension services among cassava growers. This can be done by intensification and capacity building of cassava growers on the use of the tools. By these, the cassava growers will be motivated to adopt and use the tools extensively which will invariably increase production, improve livelihood and economic growth of the nation.

\section{References}


Creative Commons User License: CC BY-NC-ND

Abstracted by: EBSCOhost, Electronic Journals Service (EJS), Google Scholar, Journal Seek, Scientific Commons,

Food and Agricultural Organization (FAO), CABI and Scopus
Journal of Agricultural Extension

Vol. 24 (1) January, 2020

ISSN(e): 24086851; ISSN(Print); 1119944X

http://journal.aesonnigeria.org

http://www.ajol.info/index.php/jae

Email: editorinchief@aesonnigeria.org

Adeniyi, R.T. (2014). Utilization of information and technologies for marketing information among cassava farmers and maize farmers in Oyo State of Nigeria. A thesis in the Department of Agricultural development, University of Ibadan, Nigeria, pp 61-72.

Ajayi, A.O., Alabi, O.S. and Okanlawon, B.I (2018). Knowledge and perception of farmers on the use of information communication technology in Ife-Central Local Government Area of Osun State: Implications for rural development. Journal of Agricultural Extension and Rural Development, Vol. 10(3): 44-53

Ani, S.O., Agbugba, I. K and Baiyegunhi J. S. (2013). Processing and marketing of selected cassava products in Southeast Nigeria. Journal of Economics,4(2): 105-111

Anzaku, T.A.K and Salau, E.S (2017). Niche marketing for farm entrepreneurs in Nigeria. Journal of Agricultural Extension, 21(3): 136-142

Ariyo, O.C. (2013). Assessment of the role of mass media in the dissemination of agricultural technologies among farmers in Kaduna State, Nigeria. Journal of Biology, Agriculture and Healthcare, 3(6): 13-17.

Asogwa, B.C and Okwoche, V.A (2012). Marketing of agricultural produce among rural farm households in Nigeria: The case of sorghum marketing in Benue State. International Journal of Business and Social Science, 3(13): 269-277.

Baltes, L. (2016). Digital marketing field specific for IT companies Marketing mix. Bulletin of the Transilvania University of Brasov Series V Pg. 7 Accessed 9 March, 2017, from URL https://masto.finna.fi/PrimoRecord/pci.proquest1833104052

Bukar, U., Mohammed, D., Wakawa, R., Shettima, B.G and Muhammad, S.T (2015). Analysis of market structure, conduct and performance for Pepper in Borno State, Nigeria: A Review. Journal of Agricultural Economics, Environment and Social Sciences, 1(1):181-190.

Fawole, O.P., and Olajide R (2012). Awareness and use of information communication technologies in Oyo State. Journal of Agricultural and Food Information, Vol. 13(4): 326-337

Federal Ministry of Agriculture and Rural Development (FMARD). (2017). Registered cassava growers' data. Federal Ministry of Agriculture and Rural Development Oyo State, Nigeria.

Kolawole, R.A., Lasisi, M.I and Adeleke, A.O (2017). Sustainability of marketing food crops through the internet in Lagos, Nigeria. Journal of Agricultural Extension, Vol. 21(1): 204-217

Lokeswari, K. (2016). A Study of the use of information communication technology among rural farmers. International Journal of Communication Research, 6(3): 232-238

Madhu, B and Deepak V. (2018). A critical review of digital marketing. International Journal of Management, Information Technology and Engineering, 8(10): 322-339

Okeke, M. N., Nwalieji, H. U. and Uzuegbunam, C. O. (2015) Emerging role of information communication technologies in extension service delivery in Nigeria: A review. Journal of Agricultural Extension, Vol.19 (1)

Olaniyi, O.A., Adetumbi, S.I and Adereti, M.A (2013). Accessibility and relevance of information and communication technologies (ICTs) among cassava farmers in Nigeria. African Journal of Agricultural Research, 8(35): 4514-4522 Retrieved 6th June, 2018, from http://www.academicjournals.org/AJAR

Oni, O.T. (2016). Socio-economic determinants and profitability of cassava production in Nigeria. International Journal of Agricultural Economics and Extension, Vol. 4(4): 229-249

Otitoju, M.A., Nweze, N.J and Ezechie, O.J (2014). Determinants of use of information and communication technologies (ICTs) among women grain marketers in Delta State, 
Creative Commons User License: CC BY-NC-ND

Abstracted by: EBSCOhost, Electronic Journals Service (EJS), Google Scholar, Journal Seek, Scientific Commons,

Food and Agricultural Organization (FAO), CABI and Scopus

http://eoi.citefactor.org/10.11226/v23i4
Journal of Agricultural Extension

Vol. 24 (1) January, 2020

ISSN(e): 24086851; ISSN(Print); 1119944X

http://journal.aesonnigeria.org

http://www.ajol.info/index.php/jae

Email: editorinchief@aesonnigeria.org

Nigeria. 19 ${ }^{\text {th }}$ Annual National Conference Proceedings of Agricultural Extension Society of Nigeria. ISSN: 1595-1421

Oyo State Diary (2010). Ministry of information, secretariat, Ibadan, Oyo State, Nigeria.

Tiamiyu, M.A., Bankole, A.S and Agbonlahor, R.O (2012). Catalytic mechanisms for promoting ICT investment and use in cassava value chains in South-western Nigeria. Journal of Information Development, Vol. 28(2):132-148 ISSN: 0266-6669

Timothy W. (2019). Marketing to farmers: A Comprehensive guide. Farm Market ID, Accessed 3rd October, 2019, from www.farmmarketid.com

Vassalos, M. and Lim, K.H (2016). Farmers willingness to pay for various features of electronic food marketing platforms in United State of America. International Food and Agribusiness Management Review, 19(2): 131-149. 